\title{
Peranan Insentif Pajak Yang Di Tanggung Pemerintah (DTP) Di Era Pandemi Covid 19
}

\author{
The Role of Government-Borne Tax Incentives in the Covid 19 Pandemic Era
}

\author{
Lili Marlinah $^{1}$ Syahribulan $^{2}$ \\ ${ }^{1}$ Universitas Bina Sarana Informatika Jakarta \\ (lili.lrh@bsi.ac.id) \\ ${ }^{2}$ Universitas Indonesia Timur Makassar \\ (syahribulansyam07@gmail.com2)
}

\begin{abstract}
ABSTRAK
Serangan pandemi Covid 19 yang terjadi secara global hampir di seluruh Negara termasuk di Indonesia telah berdampak buruk pada sektor ekonomi khususnya bisnis UMKM. Pemerintah telah melakukan berbagai upaya untuk memulihkan kembali perekonomian Indonesia, melalui Direktorat Jenderal Pajak dibawah kewenangan Kementrian Keuangan telah memberikan insentif pajak untuk wajib pajak yang terdampak pandemi Covid 19, Insentif PPh Final berdasarkan Peraturan Pemerintah Nomor 23 Tahun 2018. Peraturan ini berfokus pada Usaha Kecil dan Menengah. Pajak yang biasanya dilunasi dengan cara setor sendiri atau dipotong maupun dipungut oleh Pemotong atau Pemungut sebesar $0.5 \%$ dari penghasilan bruto, dengan adanya PMK-44/PMK.03/2020 menjadi ditanggung pemerintah berarti penghasilan tersebut menjadi tidak diperhitungkan sebagai penghasilan yang dikenakan pajak masa pajak april 2020 sampai desember 2020. Penelitian ini menggunakan metode deskriptif yakni melalui studi literatur, kepustakaan yaitu memberikan gambaran tentang aspek-aspek kehidupan masyarakat yang saat ini terkena dampak Covid-19. Tujuan pemberian insentif pajak ini kepada UMKM agar dapat mengurangi kesulitan dalam memenuhi biaya operasional atau beban pengeluaran agar UMKM bisa bertahan (Survive) selama pandemi. Dan upaya menyelamatkan perekonomian nasional dan menjaga kestabilan sistem Keuangan tercapai. Hasilnya insentif dan relaksasi pajak, pemberian insentif perpajakan untuk UMKM sektor Penerima manfaat dapat produktif dan mampu mendukung pemulihan perekonomian nasional, program dan langkah taktis menjadi upaya pertumbuhan ekonomi tetap terjaga namun program ini terpisah, sehingga tidak terkait dengan penyebaran Covid-19 yang dapat dikendalikan dengan cepat.
\end{abstract}

Kata Kunci: Covid 19, insentif, pajak, UKM, pemulihan ekonomi

\begin{abstract}
The Covid 19 pandemic attack that occurred globally in almost all countries including Indonesia has had a negative impact on the economic sector, especially the MSME business. The government has made various efforts to restore Indonesia's economy, through the Directorate General of Taxes under the authority of the Ministry of Finance has provided tax incentives for taxpayers affected by the Covid 19 pandemic, Final Income Tax Incentives based on Government Regulation Number 23 of 2018. This regulation focuses on Small Business and Intermediate. Taxes that are usually paid by selfdeposit or withheld or collected by the Withholder or Collector are 0.5\% of gross income, with PMK44 / PMK.03 / 2020 being borne by the government means that this income is not counted as income subject to tax period tax. April 2020 to December 2020. This research uses descriptive methods, namely through literature studies, literature, which provides an overview of aspects of people's lives that are currently affected by Covid-19. The purpose of providing this tax incentive to MSMEs is to reduce difficulties in meeting operational costs or expense so that MSMEs can survive (Survive) during a pandemic. And efforts to save the national economy and maintain financial system stability have been achieved. As a result, tax incentives and relaxation, providing tax incentives for MSMEs in the business sector can have room to move in the midst of the current Covid 19 pandemic. Bbeneficiaries can be productive and able to support the recovery of the national economy, programs and tactical steps are efforts to maintain economic growth but this program is separate, so it is not related to the spread of Covid-19 which can be controlled quickly
\end{abstract}

Key word: Covid 19, insentif, pajak, UMKM, pemulihan ekonomi 


\section{PENDAHULUAN}

Pandemi Covid 19 adalah sebuah epidemi yang telah menyebar ke berbagai negara atau benua, dan umumnya menjangkiti banyak orang. Serangan pandemi Covid 19 yang terjadi secara global hampir di seluruh Negara termasuk di Indonesia telah berdampak buruk pada sektor ekonomi khususnya bisnis UMKM. Dampak negatif akibat wabah Covid-19 ini menghambat roda pergerakan bisnis UMKM di seluruh Indonesia. Banyak UMKM yang terpaksa gulung tikar karena harus mengikuti aturan pemerintah untuk melakukan PSBB (Peraturan Sosial Berskal Besar) terutama usaha kecil seperti industri rumahan kuliner, kerajinan, butik, warung retail dan sebagainya harus kehilangan Omzet penjualan, Sektor usaha mikro, kecil dan menengah ini tentunya lebih rentan dalam menghadapi Covid-19, karena sejak Pandemi Covid 19 terjadi di Indonesia pada bulan Maret sampai dengan September 2020 ini hamper semua UMKM mengalami penurunan penjualan sebab ada peraturan pemerintah setempat untuk melakukan pembatasan social agar tidak terjadi kerumunan massa seperti terjadi penutupan pasar-pasar baik pasar tradisional maupun modern, penutupan mall dan restauran yang tentunya berdampak sangat serius pada kemampuan pengusaha-pengusaha kecil tersebut untuk tetap terus berusaha sehingga terjadi dampak negative secara langsung kepada kemampuan dan keberlangsungan usaha khususnya pelaku UMKM.

Beban berat yang dihadapi pelaku usaha khusunya usaha kecil yang paling nyata adalah disaat UMKM harus melakukan pembayaran cicilan atas pokok (hutang) maupun bunganya kepada perbankan sementara aktifitas penjualan menurun dan tidak ada pemasukan untuk membayar kewajiban kredit terhadap Bank, bahkan terpaksa harus merumahkan karyawan atau terpaksa melakukan pemutusan hubungan kerja (PHK). Sebelum terjadi Pandemi Covid 19 Usaha Mikro Kecil dan Menengah (UMKM) memiliki peran strategis dalam membantu pertumbuhan ekonomi nasional. Kontribusi UMKM terhadap PDB Indonesia terus meningkat sampai sekitar $60 \%$, Bahkan dari data di kementrian UMKM berkontribusi sebesar 61,7 persen terhadap Produk Domestik Bruto (PDB), atau setara dengan Rp 8.952 triliun dari total $\mathrm{Rp} 14.837$ triliun PDB Indonesia. Selanjutnya keberadaan UMKM juga dalam perekonomian nasional mencerminkan peran penting UMKM dalam pencapaian tujuan pembangunan berkelanjutan Sustainable Development Goals (SDGs) di Indonesia, karena UMKM dapat menjadi lini terdepan dalam pencapaian pilar ekonomi SDGs dengan penciptaan dan pengadaan peluang lapangan kerja, daya cipta dan inovasi bisnis untuk pertumbuhan ekonomi nasional yang inklusif dan berkelanjutan dalam menghadapi era globalisasi. Namun kondisi saat ini dalam menghadapi Pandemi Covid 19 telah menuntut, Pemerintah harus aktif berupaya memberikan penanganan pencegahan virus Covid 19, pemerintah juga bertekad untuk terus memulihkan perekonomian nasional. Berbagai program kebijakan telah dikeluarkan pemerintah, salah satunya adalah dengan pemberian Insentif pajak

bagi pelaku UMKM. Stimulus pajak ini diberikan untuk membantu wajib pajak menghadapi dampak pandemi Covid-19. Insentif pajak dapat dimanfaatkan sampai dengan Desember 2020 dengan prosedur yang lebih mudah dan bisa diurus secara Online untuk menghindari penularan Covid 19.

\section{METODOLOGI}

Penelitian ini menggunakan metode deskriptif yakni melalui studi literatur, kepustakaan yaitu memberikan gambaran tentang aspek-aspek kehidupan masyarakat yang saat ini terkena dampak Covid-19.

\section{LANDASAN TEORI}

Pada saat Pandemi Covid-19 ini Pemerintah telah memiliki kebijakan dalam menghadapi kondisi perekonmian dengan hal 
yang paling utama adalah berikap sigap dalam menyiapkan protokol atau strategi dalam menghadapi pandemi Covid -19. Kesigapan dalam menanggapi hal tersebut, Kementerian keuangan telah menyiapkan beberapa skema menghadapi krisis wabah COVID-19, beberapa diantaranya adalah menambah hutang negara untuk menambal defisit anggaran dan pemerintah juga sudah menyiapkan anggaran untuk membantu menjaga pertumbuhan ekonomi yang akan terdampak jika dilakukan karantinaEkonomi Indonesia merupakan salah satu kekuatan ekonomi berkembang utama dunia yang terbesar di Asia Tenggara dan terbesar di Asia ketiga setelah China dan India. Ekonomi negara ini menempatkan Indonesia sebagai kekuatan ekonomi terbesar ke-16 dunia yang artinya Indonesia juga merupakan anggota G-20 Sebagaimana kita ketahui bahwasanya Perekonomian menjadi sebuah pondasi kekuatan dan kemakmuran suatu Negara, karena melalui ekonomilah indikator kesejahteraan rakyat akan terlihat dimana kesejahteraan rakyat tersebut menjadi tujuan kehidupan berbangsa dan bernegara. Tidak hanya kegiatan ekonomi yang mempunyai kekuatan modal besar saja yang terdampak akibat adanya pandemi COVID19, terutama usaha yang mempunyai kekuatan modal terbatas termasuk usaha mikro, kecil dan menengah (UMKM) juga ikut terdampak karena produktivitas manusia sebagai pekerja dan pelaku usaha menjadi sangat menurun. Akibatnya stabilitas ekonomi nasional akan mengalami gangguan dan goncangan yang pada akhirnya mempengaruhi angka tingkat penurunan pertumbuhan ekonomi..

Pada saat terjadi Pandemi Covid 19 seperti ini Pemerintah berupaya untuk mendukung sektor yang paling terpukul dan terimbas, salahsatunya yakni UMKM agar tetap berdiri dan bertahan untuk terus menjalankan usahanya sehingga roda perekonomian terus berputar. Pemerintah telah mengeluarkan Peraturan Menteri Keuangan (PMK) No. 44/PMK03/2020 tentang isentif pajak untuk wajib pajak yang terdampak pandemi Corona Virus Disease 19 yang mulai berlaku tanggal 27 April 2020. Insentif dalam bentuk Pajak Ditanggung Pemerintah (P-DTP), adalah pajak terutang yang dibayar oleh pemerintah dengan pagu anggaran yang telah ditetapkan dalam Anggaran Pendapatan dan Belanja Negara, kecuali ditentukan lain dalam UndangUndang mengenai Anggaran Pendapatan dan Belanja Negara.

Sementara itu dalam upaya pemulihan ekonomi nasional, pemerintah telah berupaya mengambil berbagai kebijakan baik kebijakan fiskal dan kebijakan moneter yang komprehensif. Pemerintah juga berupaya memberikan stimulus fiskal untuk penanganan Covid 19 di berbagai sektor diantaranya sektor medis atau kesehatan, jaring pengaman sosial, dukungan industri, dan kebijakan program Pemulihan Ekonomi Nasional (PEN). Dalam upaya pemulihan ekonomi, Pemerintah juga telah mengalokasikan dana APBN yang bertujuan untuk pemulihan ekonomi sebesar Rp 695,2 triliun, diharapkan ekonomi nasional bertumbuh positif sehingga kontraksi atau bayangan resesi tahun 2020 bisa ditekan seminim mungkin dan diharapkan juga ekonomi nasional akan mengalami recovery secara siginifkan dan menyeluruh dan segera bangkit dari keterpurukan.

\section{HASIL DAN PEMBAHASAN}

Mengutip Informasi dari Badan Pusat Statistik (BPS) bahwasanya produk domestik bruto (PDB) RI pada kuartal III-2020 minus 3,49 persen (year on year/yoy). Dengan demikian Indonesia resmi masuk ke jurang resesi, setelah pada kuartal II-2020 ekonomi RI juga terkonstraksi alias negatif. Kenyataan berat ini sebagai imbas dari adanya Pandemi Corona Virus Disease 2019 (COVID- 19), dimana tidak saja berdampak pada buruknya kesehatan tubuh manusia, tetapi telah memberi dampak pula terhadap memburuknya kondisi perekonomianyang ditunjukkan dengan penurunan berbagai aktivitas ekonomi nasional.

Sebagaimana telah diuraikan diatas bahwa Pemerintah telah meluncurkan Program Pemulihan Ekonomi Nasional 
merupakan langkah pemerintah dalam upaya melindungi, mempertahankan dan meningkatkan kemampuan ekonomi para pelaku usaha dari sektor riil dan sektor keuangan dalam menjalankan usahanya selama pandemi Covid-19. Kebijakan pemulihan ekonomi nasional yang digaungkan pemerintah ini diharapkan bisa membantu meringankan beban sektor yang terimbas covid 19.

Pemerintah kini telah mengambil langkah dan strategi khusus kebijakan dengan program-program yang bertujuan dalam penyelamatan perekonomian nasional dan stabilitas sistem keuangan melalui berbagai kebijakan relaksasi yang berkaitan dengan pelaksanaan Anggaran Pendapatan dan Belanja Negara (APBN). Bapak Presiden Joko Widodo telah mengalokasikan anggaran untuk pemulihan ekonomi nasional sebesar Rp 356,5 triliun, yakni salah satunya untuk penanganan bidang kesehatan sebesar $\mathrm{Rp}$ 25,4 triliun dan bidang perlindungan sosial Rp 110,2 triliun. Sementara APBN untuk bantuan UMKM sekitar Rp 48,8 triliun yang diberikan melalui subsidi bunga KUR, pembiayaan UMKM, penjaminan serta penempatan dana di perbankan agar dapat bermanfaat bagi dunia usaha untuk bangkit kembali.

Pemerintah berupaya melakukan perlindungan sosial kepada lebih dari 103 juta masyarakat Indonesia dengan memberikan bantuan dari pemerintah berupa bantuan sosial senilai 65 triliun yang dilaksanakan secara bertahap dan merata Bantuan sosial berupa paket-paket sembako untuk membantu rumah tangga atau masyarakat, dimana paket bansos tersebut diberikan sejak awal pandemi Covid-19 terjadi di Indonesia sampai September 2020 ini dan akan terus diberikan sampai pandemic berakhir. Bantuan sosial ini diberikan bagi warga di DKI Jakarta dan wilayah Bogor, Depok, Tangerang, Tangerang Selatan, dan Bekasi. Tidak hanya bansos tetapi pemerintah juga memberikan bantuan tunai yang ditujukan untuk warga di luar Jabodetabek. Program ini memberikan dana secara tunai yang masuk ke rekening masyarakat sebesar Rp 600.000 kepada masyarakat selama 3 bulan, yakni April, Mei, dan Juni 2020. Begitu juga dengan adanya program kartu prakerja, subsidi listrik, bantuan desa dan sebagainya.

Mengurai kembali pada kebijakan pemulihan ekonomi nasional, Pemerintah telah menerbitkan Peraturan Pemerintah Nomor 23 Tahun 2020 (PP 23/2020) tentang Pelaksanaan Program Pemulihan Ekonomi Nasional Untuk Mendukung Kebijakan Keuangan Negara Untuk Penanganan Pandemi Corona Virus Disease 2019 (Covid19) Dan/Atau Untuk Menghadapi Ancaman yang membahayakan Perekonomian Nasional Dan/Atau Stabilitas Sistem Keuangan Serta Penyelamatan Ekonomi Nasional (PEN). Peraturan ini merupakan turunan peraturan perundang-undangan mengenai penanganan Covid-19 dimana mengatur mengenai mekanisme intervensi pemerintah dalam pelaksanaan Program PEN melalui penyertaan modal negara, penempatan dana, investasi pemerintah, dan penjaminan. Sementara maksud dari pilihan skema intervensi akan disesuaikan dengan kebutuhan yakni target kelompok pelaku usaha yang akan diberikan stimulus-stimulus dengan tetap mempertimbangkan kemampuan keuangan negara.

\section{Pada Peraturan Pemerintah Nomor} 23/2020 juga mengatur bahwa Pemerintah dapat melakukan program pemulihan ekonomi melalui berbagai cara yakni salahsatunya pengalokasian belanja Negara dengan memberikan subsidi bunga bagi kelompok pelaku usaha mikro, kecil dan menengah yang terdampak Covid-19 dan sudah berupaya melakukan restrukturisasi kreditnya pada perbankan, mengajukan keringanan pada perusahaan pembiayaan agar mendapat atau memperoleh fasilitas subsidi bunga untuk keringanan cicilan, penundaan pembayaran hutang pokok atau jangka waktu yang diperpanjang. Mengutip informasi dari Otoritas Jasa Keuangan (OJK) melaporkan bahwasanya realisasi restrukturisasi kredit perbankan mencapai Rp904,3 triliun per tanggal 28 September 2020. Dari data yang ada Restrukturisasi 
tersebut diberikan kepada 7,5 juta nasabah yang terdiri dari 5,82 juta debitur usaha mikro, kecil, dan menengah (UMKM) dan 1,64 juta debitur non UMKM.

Seperti yang telah diuraikan diatas bahwa dalam rangka menghadapi permasalahn yang membahayakan perekonomian Nasional dan atau stabilitas sistem keuangan menjadi Undang-Undang. Maka Program PEN ini ditujukan untuk membantu, mendorong, meningkatkan daya beli masyarakat serta memulihkan perekonomian Indonesia secara merata dan keseluruhan. Berfokus pada rumah tangga masyarakat yang paling rentan atas dampak Covid 19 kemudian pada sektor usaha (UMKM). Pemerintah juga akan fokus pada strategi untuk mengurangi risiko kontraksi ekonomi di kuartal 3 dan di kuartal 4 tahun 2020 dengan melakukan optimalisasi atas potensi anggaran-anggaran yang kemungkinan belum atau tidak terserap dengan melakukan re-alokasi ke programprogram yang dapat terlaksana dan selesai di tahun 2020 shingga roda kehidupan perekonomian diharapkan bisa berputar kembali. Program Pemulihan Ekonomi Nasional dimaksud adalah sebagai berikut :

1. Menganggarkan belanja penanganan Covid-19

2. Melakukan perlindungan sosial melalui Bantuan sosial kepada masyarakat berpenghasilan rendah

3. Membantu Pemda dan Sektoral dengan program Padat Karya

4. Subsidi bunga UMKM

5. Pembiayaan Korporasi

6. Insentif usaha berupa pajak

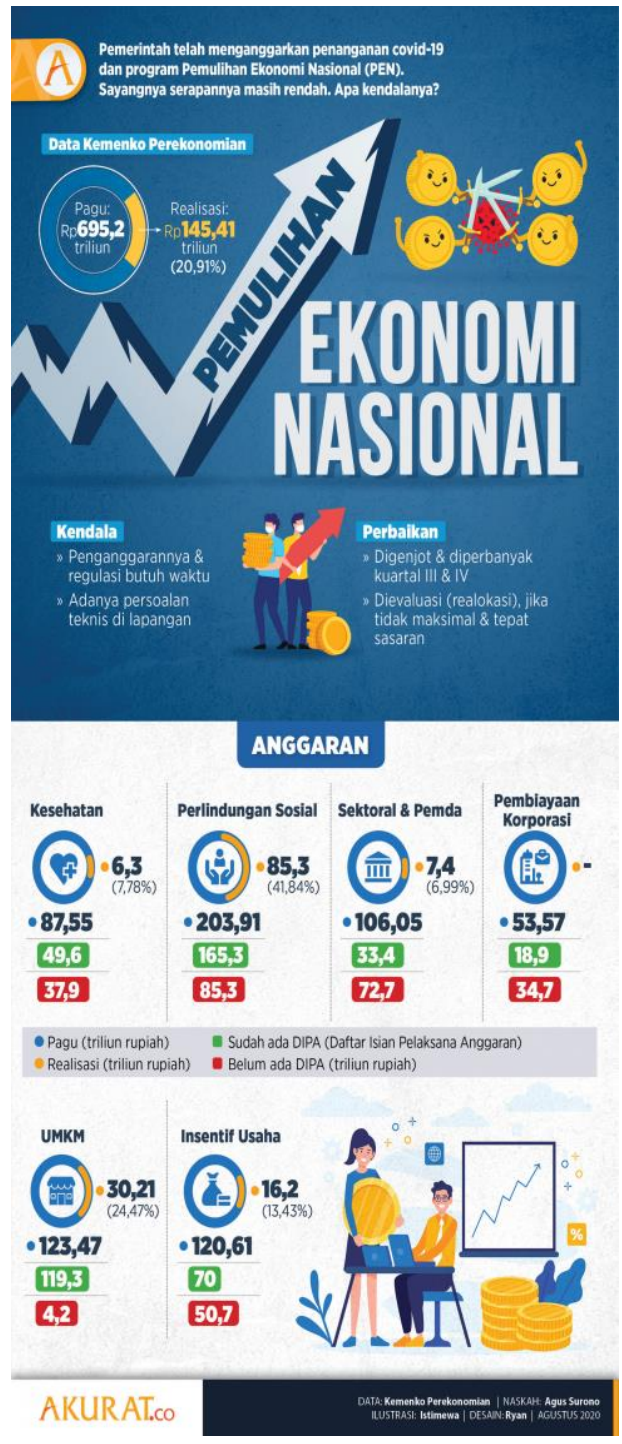

Gambar 1

Program Pemulihan Ekonomi

Mengacu pada program PEN dengan pemberian insentif usaha berupa keringan pajak, Seperti diketahui, sejak 2018 pengusaha Usaha Mikro, Kecil dan menengah (UMKM) telah dipungut pajak penghasilan final sebesar 0,5 persen. Insentif pajak UMKM ini ini tertuang dalam Peraturan Pemerintah (PP) Nomor 23/2018 tentang Pajak Penghasilan atas Penghasilan dari Usaha yang Diterima atau Diperoleh Wajib Pajak yang Memiliki Peredaran Bruto Tertentu (Dibawah 4.8Milyar per tahun), maksudnya agar kelompok UMKM tetap dikenakan kewajiban membayar Pajak Penghasilan $(\mathrm{PPh})$ yang didasarkan pada 
jumlah peredaran bruto tertentu yang ditetapkan pemerintah sebagimana gambar dibawah ini:

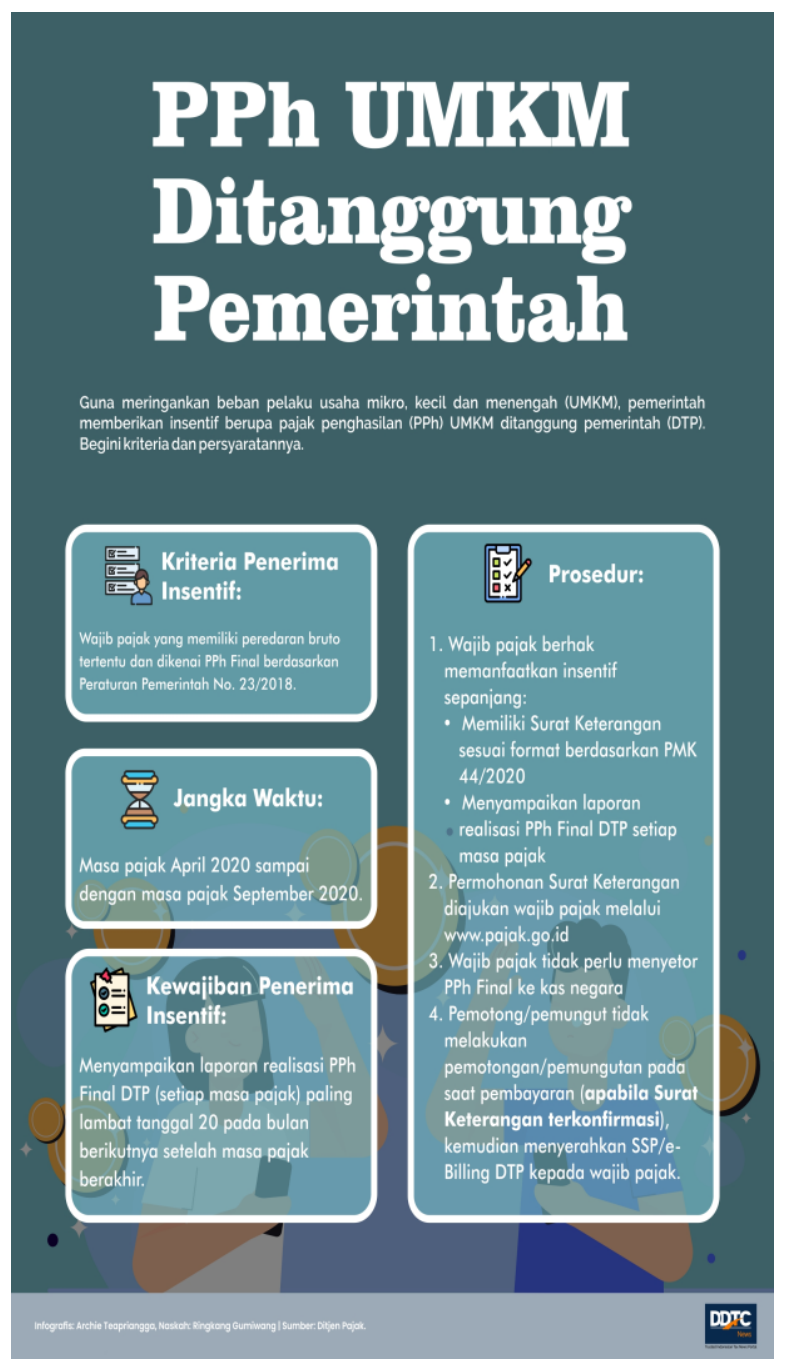

Gambar 2

PPh UMKM Ditanggung Pemerintah

Dengan situasi dan kondisi yang cukup berat untuk perekonomian nasional di tengah pandemi Covid 19, pemerintah akhirnya memberi perluasan kebijakan yakni insentif pajak bebas PPh Final bagi UMKM melalui Peraturan Menteri Keuangan (PMK) Nomor 44/PMK.03/2020 tentang Insentif Pajak untuk Wajib Pajak terdampak Covid 19, Maka peraturan ini merupakan perubatan atas PMK No. 23/PMK.03/2020 tentang Insentif Pajak untuk wajib terdampak wabah virus Covid 19.
Selain memberikan insentif pajak berupa bebas PPh Final bagi UMKM, PMK No. 44/2020 ini juga memberikan perluasan sektor usaha penerima insentif diskon angsuran $\mathrm{PPh} 25$, insentif Pajak Pertambahan Nilai (PPN), pembebasan $\mathrm{PPh}$ 22 Impor, dan perluasan penerima pembebasan $\mathrm{PPh}$ 21. Berdasarkan pada kebijakan ini, UMKM dapat mengajukan pembebasan pajak penghasilan final sebesar $0,5 \%$, maka untuk setiap transaksi yang dilakukakan oleh UMKM tidak perlu lagi menyetor pajak dan pemotong atau pemungut pajak tidak lagi memotong atau memungut pajak kepada pelaku UMKM.

Dalam mendapatkan fasilitas insentif pajak maka syarat dan cara mengajukan Insentif PPh Final UMKM yang ditanggung pemerintah adalah sebagai berikut:

a) UMKM Mengajukan dan memiliki Surat Keterangan PP 23 kepada kantor pajak setempat

b) Pengajuan permohonan melalui laman www.pajak.go.id

c) Membuat laporan realisasi $\mathrm{PPh}$ Final DTP setiap Masa Pajak, yang meliputi $\mathrm{PPh}$ terutang atas penghasilan yang diterima atau diperoleh termasuk dari transaksi dengan pemotong atau pemungut

d) Pemotong atau pemungut pajak harus membuat Surat Setoran Pajak atau cetakan kode billing yang dibubuhi cap atau tulisan "PPh Final Ditanggung Pemerintah Eks PMK Nomor.../PMK.03/2020" atas transaksi yang merupakan objek pemotongan atau pemungutan $\mathrm{PPh}$

e)Laporan realisasi $\mathrm{PPh}$ final DTP dilampiri dengan Surat Setoran Pajak atau cetakan kode billing harus disampaikan paling lambat 20 bulan berikutnya setelah masa pajak berakhir 


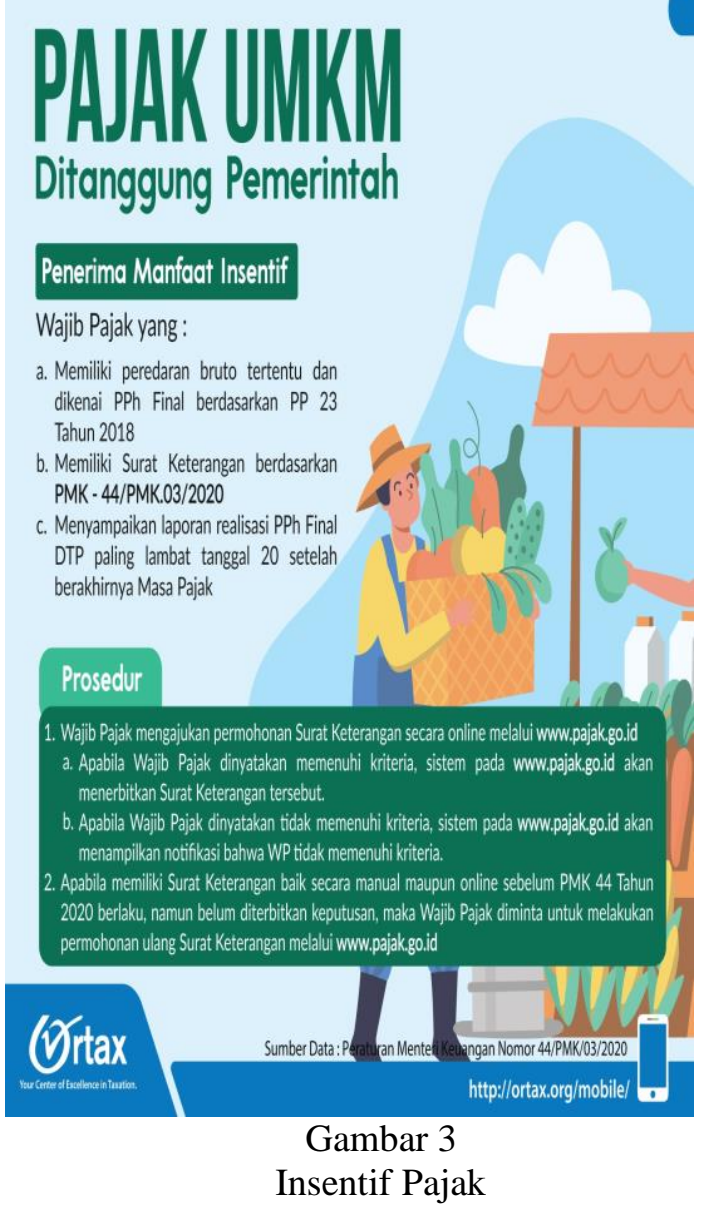

Sementara itu Pph UMKM Ditanggung Pemerintah adalah Pemerintah menanggung $\mathrm{PPh}$ Final yang seharusnya dibayarkan oleh pelaku usaha UMKM yang peredaran brutonya dibawah 4,8 miliar rupiah per tahun. Kebijakan pemberian insentif pajak penghasilan (PPh) final ditanggung pemerintah (DTP) bagi Usaha Mikro Kecil \& Menengah (UMKM) yang awalnya sampai 30 September ini diperpanjang sampai Desember 2020. Informasi yang diperoleh dari catatan otoritas pajak, saat ini baru ada 201.000 usaha mikro, kecil, dan menengah (UMKM) yang memanfaatkan insentif Pajak Penghasilan (PPh) final ditanggung pemerintah, kemungkinan pelaku UMKM masih belum memahami kebijakan insentif pajak ini karena jumlah wajib pajak UMKM yang tercatat membayar $\mathrm{PPh}$ final pada 2019 sebanyak 2,3 juta pelaku usaha, jadi dengan jumlah yang masih terbatas ini bisa dikatakan belum banyak UMKM yang memanfaatkan insentif pajak ini. Pemerintah masih terus berupya agar UMKM bisa lebih memahami manfaat insentif pajak ini maka diperlukan kordinasi dan kolaborasi lintas sektoral dalam melakukan sosialisasi danedukasi, sehingga bisa meningkatkan literasi perpakan yang akhirnya bisa menggerakan kembali roda perekonomina ditengah mewabahnya Covid 19 di Indonesia. Untuk mendapatkan insentif $\mathrm{PPh}$ final DTP, wajib pajak khusunya UMKM harus mengajukan surat keterangan sesuai dengan PMK No 44/2020 dimana surat keterangan sebagaimana dimaksud hanya dapat diperoleh Wajib Pajak termasuk yang telah memiliki Surat Keterangan sebelum Peraturan Menteri ini berlaku dengan mengajukan permohonan kepada Direktur Jenderal Pajak melalui saluran tertentu pada laman www.pajak.go.id. Setelah mendapatkan surat keterangan, wajib pajak juga harus menyampaikan laporan realisasi pemanfaatan insentif $\mathrm{PPh}$ final DTP paling lambat setiap tanggal 20 pada bulan berikutnya setelah berakhirnya masa pajak. Surat keterangan harus sudah dimiliki paling lambat sebelum penyampaian laporan realisasi. Selain itu ketentuan ini harus segera dilakukan, tidak hanya kepada wajib pajak,akan tetapi juga kepada para pemotong $\mathrm{PPh}$ final yang melakukan transaksi dengan wajib pajak. Karena apabila hal ini tidak atau terlambat diketahui, insentif PPh final DTP kurang termanfaatkan oleh wajib pajak. 


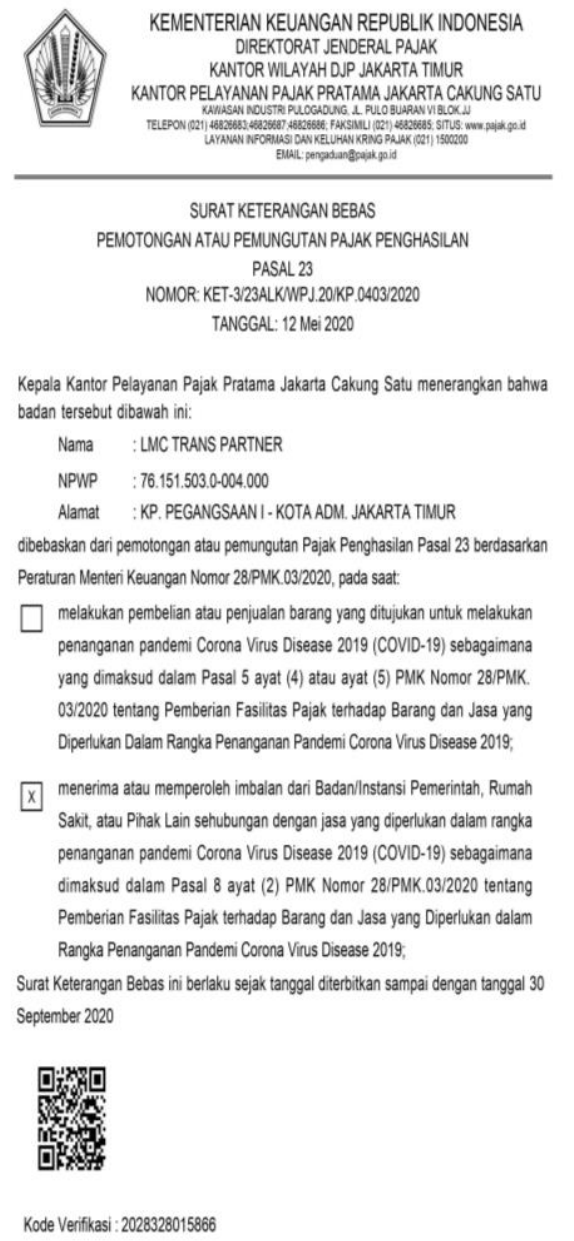

Gambar 5

Surat Keterangan

Diatas adalah contoh surat keterangan untuk pajak yang ditanggung pemerintah, diuraikan bahwa wajib pajak adalah UMKM yang diberikan fasilitas insentif pajak yang ditanggung pemerintah. Dengan adanya surat keterangan tersebut maka bila ada transaksi yang dilakuakan oleh UMKM tersebut tidak ada pajak yg dibayarkan karena pajak Pph nya ditanggung pemerinta. UMKM hanya melampirkan surat keterangan tersebut di Invoice tagihannya dan setiap bulan melaporkan realisasi nya melalui DJP online. Sementara itu diperoleh informasi dari Kementrian Koperasi dan UKM terdapat lima skema perlindungan dan pemulihan UMKM di tengah pandemi Covid-19 yakni pelaku UMKM miskin dan rentan yang masuk kategori penerima Bansos, Insentif pajak bagi UMKM dengan omzet kurang dari Rp4,8 miliar per tahun dan tarif PPH final nol persen selama enam bulan periode April-September 2020 yang kemudian diperpanjang sampai Desember 2020. Relaksasi dan restrukturisasi kredit bagi UMKM berupa penundaan angsuran dan subsidi bunga kredit diperluas untuk usaha mikro penerima bantuan usaha dari Pemda. Termasuk KUR, UMi, PNM, Mekaar dan LPDB UMKM. Perluasan pembiayaan modal kerja UMKM ditujukan agar terhubung terhubung dengan lembaga pembiayaan atau perbankan. Kementerian, BUMN, dan pemda sebagai penyangga produk UMKM di bidang pertanian, perikanan, kuliner, dan industri rumah tangga.

\section{KESIMPULAN}

Insentif pajak menjadi salah satu langkah kebijakan yang pemerintah yang diambil dalam menghadapi penurunan ekonomi akibat serangan Covid-19. Program Pemulihan Ekonomi Nasional juga diharapkan berjalan sesuai dengan tujuannya, $P P$ No. 23/2020 mengatur prinsip pelaksanaan program PEN yang terdiri atas asas keadilan sosial yang sebesar-besarnya untuk kemakmuran rakyat. Sebagai salah satu program PEN adalah Insentif perpajakan, maka yang dimaksud adalah pajak penghasilan (PPh) Pasal 21 ditanggung pemerintah (DTP), pembebasan PPh Pasal 22 impor selama 6 bulan, percepatan restitusi pajak pertambahan nilai (PPN), serta peringanan PPh Pasal 25 sebanyak 30\%.

Dalam upaya menyelamatkan perekonomian nasional dan menjaga kestabilan sistem keuangan, Pemerintah menerapkan Elliyana and Bachtiar 2020) standar $20 \%$ platfon pembiayaan atau kredit perbankan kepada UMKM, selain itu insentif dan relaksasi pajak, bersama dengan sejumlah kebijakan lainnya yang diatur dalam Peraturan Pemerintah Pengganti Undang-Undang. Pemberian insentif perpajakan untuk UMKM agar sektor usaha dapat memiliki ruang untuk bergerak di 
tengah kondisi pandemic Covid 19 seperti saat ini. Pemerintah melalui Dirjen Pajak akan terus melakukan Hasilnya insentif dan relaksasi pajak, pemberian insentif perpajakan untuk UMKM sektor usaha dapat memiliki ruang untuk bergerak di tengah kondisi pandemic Covid 19 seperti saat ini. Sosialisasi kepada pelaku UMKM terkait adanya insentif pajak ini,penerima manfaat dapat produktif dan mampu mendukung pemulihan perekonomian nasional, program dan langkah taktis menjadi upaya pertumbuhan ekonomi tetap terjaga namun program ini terpisah, sehingga tidak terkait dengan penyebaran Covid-19 yang dapat dikendalikan dengan cepat.

\section{UCAPAN TERIMA KASIH}

Puji syukur penulis panjatkan kehadirat Allah Subhanahu Wata'ala karena dengan rahmat dan hiyah-Nyalah sehingga penulis dapat menuntaskan artikel ini dengan judul "Peranan Insentif Pajak Yang Di Tanggung Pemerintah (DTP) Di Era Pandemi Covid 19"

\section{DAFTAR PUSTAKA}

Elliyana, E. a. (2020). Financing Comparison Of Umkm Conventional Banks And Syariah Banks In Indonesia. Business And Entrepreneurial Review (Ber), 99108.

Rabia, A. B., \& Mulyani, R. S. (2019). Analisis sistem pengawasan pemberian pembiayaan pada $\mathrm{PT}$. Bank Sulselbar Syariah Cabang Utama Makassar. Economy Deposit Journal (E-DJ), 1(1), 1-8.

Usman, M., \& Shaleh, M. (2019). The Influence Of Information Quality, Tax Service Information, And Perceived Ease Of Use On Personal Taxpayer Compliance At Kpp Makassar Pratama Utara. Economy Deposit Journal (E-DJ), 1(2), 24-32. http://id.wikipedia.org/wiki/Pertumbu han_ekonomi http://indonesiakreatif.bekraf.go.id/ikpro/pro grams/apa-itu-ekonomi-kreatif

www.bps.go.id

www.kemenkue.go.id

Www.bapenas.go.id

Sudaryanto, Ragimun. 2011. Strategi Pemberdayaan UMKM Menghadapi Pasar Bebas Asean. Yogyakarta: Kedaulatan Rakyat

http://www.depkop.go.id/read/menkop-danukm-paparkan-skema-pemulihanekonomi-kumkm-di-masa-dan-pascacovid-19, diakses 22 November 2020 Jam 19.05

https://www.kemenkeu.go.id/publikasi/siara n-pers/siaran-pers-desain-programpemulihan-ekonomi-nasional-untukumkm-dan-dunia-usaha-rampungpemerintah-terbitkan-aturan-pp232020/, diakses 22 November 2020 Jam 21.15 